\title{
CARD8 wt Allele
}

National Cancer Institute

\section{Source}

National Cancer Institute. CARD8 wt Allele. NCI Thesaurus. Code C84305.

Human CARD8 wild-type allele is located in the vicinity of 19q13.33 and is approximately

$41 \mathrm{~kb}$ in length. This allele, which encodes caspase recruitment domain-containing protein 8 , plays a role in the modulation of both caspase activity, and apoptosis. 